Ethnobiology and Conservation, 10:10 (2021) doi:10.15451/ec2020-11-10.10-1-13

ISSN 2238-4782 ethnobioconservation.com

\title{
Conservation of Amazonian manatee (Sirenia: Trichechidae): the case of Extractive Reserve Verde para Sempre, Brazil
}

\author{
Cinthia Magali Moreira Hoffmann ${ }^{1}$; Samantha Ribeiro da Silva ${ }^{1}$; Angélica Lúcia \\ Figueiredo Rodrigues $^{2}$; Pedro Chaves Baia-Júnior ${ }^{3}$; Yvonnick Le Pendu ${ }^{4}$ and \\ Diva Anelie de Araújo Guimarães ${ }^{2 *}$
}

\begin{abstract}
Found in the main rivers of the Amazon Basin, the Amazonian manatee (Trichechus inunguis) is the largest aquatic freshwater mammal in South America. The objective of this study was to describe the ecological knowledge and uses of the Amazonian manatee in the Extractive Reserve Verde para Sempre, Porto de Moz, Brazilian Amazon. This study was conducted through semi-structured interviews, free interviews, participant observation and image capture. Thirty-one residents were interviewed in 21 communities, using snowball sampling method. The interviewees were previously identified by local informants and selected according to their level of knowledge of the species. We collected information on the morphology, behavioral characteristics and feeding habits of manatees, and on the uses of the species by communities. Our findings suggest three hypotheses on the biology of Amazonian manatee: 1- the existence of three phenotypic patterns based on skin color and amount of fat; 2- changes in land use by agriculture, livestock and the installation of the hydroelectric plant affect their spatial distribution and seasonal migration; 3- they show reproductive behavior during the rainy season, in a polygamous way as a strategy of maintenance and genetic variability of the species. One third of the interviewees learned of the prohibition of manatee poaching during the implementation of the reserve. Poaching and consumption of manatees are rare, and entanglement of calves in fishing nets is accidental. These results reinforce the interest of local ecological knowledge in understanding the biology of the Amazonian manatee and their contribution to the delimitation of protected areas.
\end{abstract}

Keywords: Trichechus inunguis; Ethnoecology; Protected Area; Poaching; Amazon.

\footnotetext{
1 Programa de Pós-graduação em Biodiversidade e Conservação, Altamira Campus, Universidade Federal do Pará, Rua Coronel José Porfírio n⿳0 2515, Altamira, PA, 68372-040, Brazil.

2 Instituto de Ciências Biológicas, Universidade Federal do Pará. Rua Augusto Corrêa no 1, Guamá, Belém, PA, 66075-110, Brazil. 3 Instituto Federal de Educação, Ciência e Tecnologia do Pará, Rua Rio Grande do Sul no3322, 68440-000, Abaetetuba-Pará, Brazil. 4 Universidade Estadual de Santa Cruz, Departamento de Ciências Biológicas, Rodovia Jorge Amado, km 16, 45662-900, Ilhéus, BA, Brazil.

* Corresponding author $\bowtie$. E-mail address: DAAG (diva@ufpa.br)
} 
Hoffmann et al. 2021. Conservation of Amazonian manatee (Sirenia: Trichechidae): the case of Extractive Reserve Verde para Sempre, Brazil

Ethnobio Conserv 10:10

\section{SIGNIFICANCE STATEMENT}

The main motivation of this work is to show the role of traditional communities who live in protected areas in the conservation of the Amazonian manatee. The ecological knowledge of the interviewees about this vulnerable species is useful to develop a scenario for the conservation of the species.

\section{INTRODUCTION}

The loss of biodiversity, the degradation of the productive capacity of water cycling and carbon storage ecosystems affect the human populations that inhabit the Brazilian Amazon (Fearnside 2003). The growing territorial occupation of this region has led to deforestation to develop ranching, family and mechanized agriculture. The current challenge is to elaborate sustainable strategies that aim to order the socioeconomic development through the management of natural resources (Alencar et al. 2004). Amazonia is the most diverse tropical forest zone (Da Silva et al. 2005) with numerous endemic species (Kress et al. 1998). The endemic Amazonian manatee, Trichechus inunguis, occurs in a large part of the amazon basin, but are patchily distributed in nutrient-rich areas (Marmontel et al. 2016). The species is threatened by anthropic actions (Venter et al. 2016) such as deforestation (Ripple et al. 2016), the construction of hydroelectric plants (Lees et al. 2016), mining activities (Tófoli et al. 2017) and intense navigation and fishing (Isaac et al. 2015).

The hunting of the Amazonian manatee was widely practiced by the native population of the Amazon for their food subsistence. Its exploitation by non-indigenous populations probably began in 1542 and continued until 1954 (Marmontel et al. 2012; Antunes et al. 2016). Professional hunting and trading of wild fauna has been prohibited in Brazil since 1967 by Law 5197/67 (BRASIL 1967), but manatees are still hunted today on a much smaller scale (Marmontel et al. 2012). The Amazonian manatee has been listed as vulnerable to extinction by IUCN since 1982, primarily due to poaching pressure, coupled with climatic, environmental and anthropic factors (Marmontel et al. 2016). In addition to its consumption, parts of the animal are used as medicine and magicalreligious symbols (Rosas and Pimentel 2001; Zaniolo 2006; Castelblanco-Martínez et al. 2016).

There are still gaps to be filled about the biology of the Amazonian manatee (Kendall et al. 2014; Silva et al. 2014; Castelblanco-Martínez et al. 2016). For example, there is little information about reproduction, behavior, nutrition, and poaching of this species in the lower Xingu river, Brazil. The understanding of some of these biological and environmental aspects, related to population dynamics, is fundamental to know the basic requirements of the species, and consequently its conservation.
Due to the difficulty in sighting Amazonian manatees, it is essential to develop alternative techniques to direct observation that can provide information about the ecology of this species. Traditional ecological knowledge has provided relevant data to assist the development of sustainable management models (Jepson and Ladle 2009; Jenkins et al. 2011; Zappes et al. 2014; Ramirez-Gomez et al. 2015), suggesting new biological and ecological hypotheses (Silvano and Valbo-Jørgensen 2008; Silvano and Begossi 2010; Ruddle and Davis 2011). For example, a hypothesis on the availability and distribution of the parrotfish green humphead (Bolbometopon muricatum) in a lagoon in the Western Solomon Islands was elaborated based on local indigenous ecological knowledge and corroborated by biological studies (Aswani and Hamilton 2004). However, hypotheses generated from local ecological knowledge can also be refuted: claims by Canadian fishermen that white hake (Urophycis tenuis) was the main predator of juvenile lobster (Homarus americanus) have not been confirmed by a multidisciplinary scientific study (Ruddle and Davis 2011). In addition, ethnozoological studies are useful to investigate the different motivations and ways of using wildlife by human populations (Bezerra et al. 2013; Morsello et al. 2015; Alves and Rocha 2018). Therefore, we consider that the local ecological knowledge on the Amazonian manatees can contribute to the conservation of the species and improve its management by providing new information on the ecology of the species, including its distribution, diet, reproduction, and uses by human communities.

The main objectives of this study are: (1) to describe the local ecological knowledge and the uses of the Amazonian manatee by residents of a Federal Conservation Unit; (2) to characterize the spatial distribution of Amazonian manatees during the dry and rainy seasons according to reproductive status and forage availability; (3) assess the pattern of poaching of manatees.

\section{MATERIAL AND METHODS}

This study was conducted in the extractive reserve RESEX Verde para Sempre (meaning green forever), a Federal Conservation Unit established in 2004, with an area of 1.289.363 ha, one of the largest extractive reserves in the Brazilian Amazon. The reserve is located in the municipality of Porto de Moz in the lower Xingu region, Pará, Brazil ( $01^{\circ} 31^{\prime} 50^{\prime \prime}$ and $02^{\circ} 47^{\prime} 55^{\prime \prime} \mathrm{S}$, 
and $52^{\mathrm{O}} 06^{\prime} 43^{\prime \prime}$ and $\left.53^{\mathrm{O}} 23^{\prime} 06^{\prime \prime} \mathrm{W}\right)$, in the western region of the state of Pará, Brazil (ICMBio 2013). The reserve aims to ensure the sustainable use and conservation of renewable natural resources, protecting the livelihood and culture of the local population (ICMBio 2013), made up of 8964 residents in 57 rural communities.

The RESEX is bordered to the north by the Amazon river, to the east by the Xingu river, and cut by the Acarai, Jauruçu and Guajará rivers and their various tributaries (Figure 1). Porto de Moz has an average annual rainfall of $2337 \mathrm{~mm}$ and is characterized by a rainy season (December to May) and a dry season (June to November) (De Paula and Da Silva 2019).

The research was carried out in 21 communities, from September 2015 to August 2016: we conducted two field trips during the rainy season and three during the dry season. The purposes of the study were clarified to the residents, then the interviews were applied only to those who agreed to participate in the research.

Data collection consisted in the application of semi-structured interviews, free interviews, participant observation and image capture (Albuquerque et al. 2014). Participants $(n=31)$ were initially suggested by local leaders and then by the first interviewees, using the snowball sampling method (Bailey 1994). This inexpensive method is usable in a specific population and with difficult access. Since the focus of study of this work is ethno knowledge, we consider the snowball approach appropriate. However, because it is a non-probabilistic technique, it does not allow to determine the degree of precision and the representativeness of the sample size.

Before the application of the questionnaire, the participants were informed about the objective and methodology of the survey. The participants were assured of the confidential and private character of the interviews, through the signature of a Free and Informed Consent Form, guaranteeing the non-use of the information for other purposes than the study itself. The application of an interview was suspended when discomfort related to embarrassing questions was perceived, respecting the habits and customs of the local society.

The present study investigated the socioeconomic profile of the interviewees, identifying sex, age, profession, education, time of local residence, fishing and farming, aiming to relate the impacts caused by these activities to the ecosystem and, consequently, the Amazonian manatee conservation. Ethnoecological knowledge about phenotype, reproduction, behavior and uses of the species by communities (poaching, demand and trade) was also investigated. The potential food items of the Amazonian manatee were identified, based on the traditional knowledge of the par- ticipants. The plant species consumed by the Amazonian manatees were identified through images and the literature (Best 1981; Colares 1991; Colares and Colares 2002; Guterres-Pazin 2010).

The level of experience and knowledge about the Amazonian manatee considered the time of coexistence of the participants with the species in the places where they could supposedly observe manatees and their habits for a long period of time. Furthermore, there was a male predominance $(n=30)$ due to the transmission of fishing and hunting techniques by fathers and grandfathers during the practice of these activities. The data collected were analyzed through qualitative exploratory analysis, which is characterized by the research of phenomena that occur at the study site, as well as the existing empirical knowledge (Vergara 2012).

\section{Ethical Aspects}

We conducted our study following the rules and guidelines of the National Health Council (Resolution 466/12) (BRASIL 2013). This work was approved by the Chico Mendes Institute for Biodiversity Conservation (ICMBio), Ministry of the Environment (SISBIO - 50636-1 / 2015), and by the Research Ethics Committee of the Health Sciences Institute of the Federal University of Pará (CAAE-52449315.3.0000.0018).

\section{RESULTS}

The 31 residents of RESEX Verde para Sempre interviewed were between 30 and 78 years old and almost all were born in the community $(97 \%, n=30)$. The levels of education observed were as follows: $32 \%$ $(n=10)$ illiterate; $42 \%$ with incomplete elementary education; $13 \%$ with complete elementary education; $3 \%$ with incomplete secondary education; $6 \%$ with complete secondary education; and $3 \%$ with incomplete higher education.

The main socioeconomic activities were the following: farming (manioc, Manihot esculenta; watermelon, Citrullus lanatus; corn, Zea mays; rice, Oriza sp.; and pumpkin, Cucurbita spp.), breeding (water buffalo, Bubalus bubalis and cattle, Bos taurus), fishing (pirarucu, Arapaima gigas; tambaqui, Colossoma macropomum; and streaked prochilod, Prochilodus lineatus, among others), and plant extraction (titica vine, Heteropsis spp., and Brazil nut, Bertholletia excelsa). Breeding of large domestic animals (B. bubalis and B. taurus) was practiced by $77 \%(n=24)$ of the interviewees.

The Amazonian manatee was recognized as a large animal with mouth, snout, small eyes, fin (called a paddle) and a paddle-shaped tail. The difference between males and females was determined by the size of 

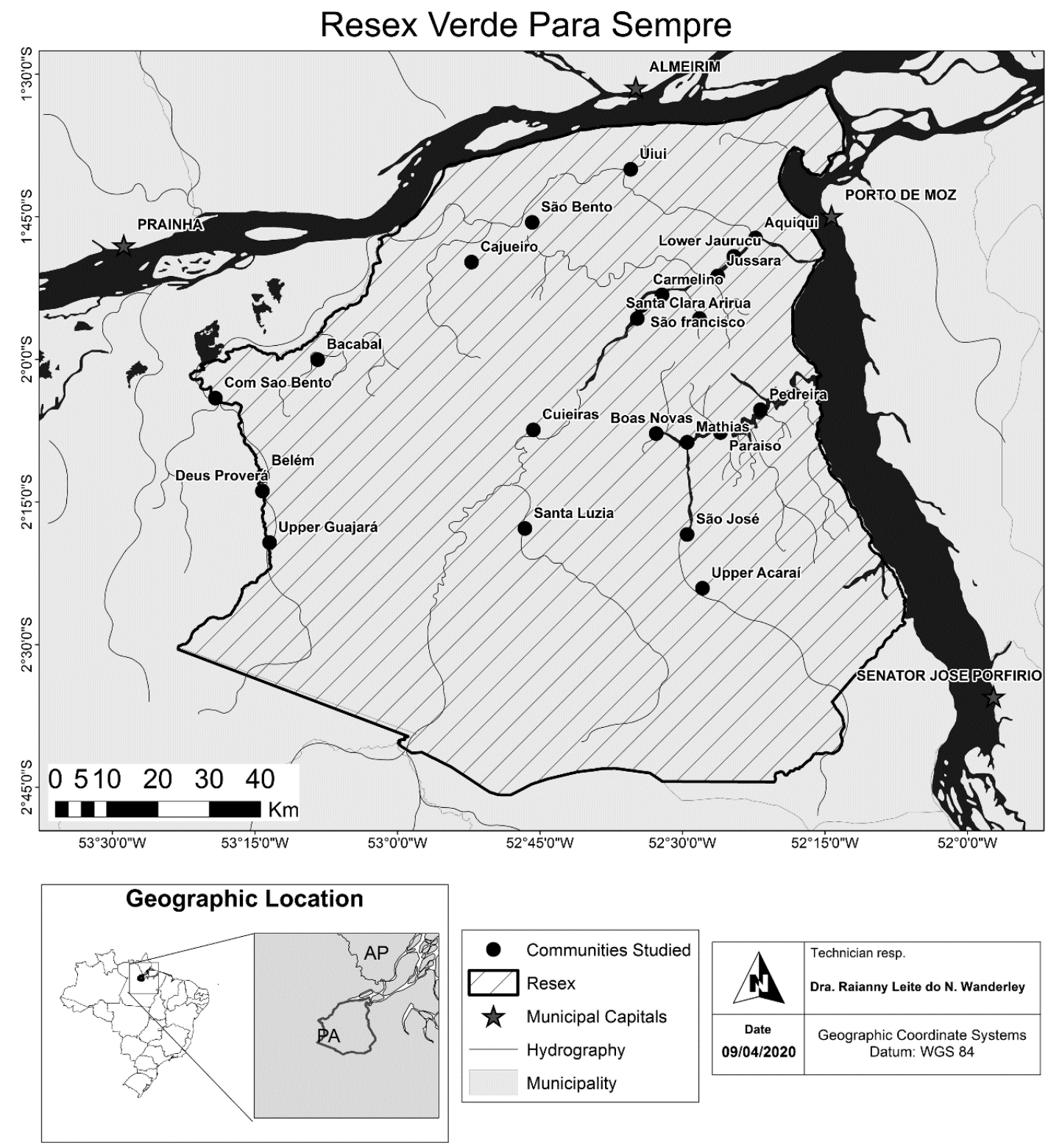

Figure 1. Extractive Reserve RESEX Verde para Sempre, Porto de Moz, Pará.

the snout exposed out of water, when the animal surfaces to breathe: the male exposes most of the muzzle, while the female only leans against the surface of the water. According to $30 \%(n=9)$ of the respondents, the meat of Amazonian manatee tastes like beef in the anterior part and fish in the posterior part of the body (Figure 2).

The interviewees discriminated three Amazonian ethnospecies of manatee (Table 1), based on skin color and amount of fat: 1) the black manatee or Poca a small, black and spotless animal; 2) the common manatee or Rosilho - a gray animal with a white or rosy chest spot (the most common type in the region); and 3) the butter manatee - large in size, with a high amount of fat.

According to interviewees, manatees can be found in all rivers of the reserve, but are predominantly observed in open and deep sections (called Poços) that are located near large flooded fields. Manatees remain in these places during the rainy season. According to the majority of the respondents $(74 \%, n=23)$, food supply decreases during the dry season, and the manatees move further away from human communities to an area located at the headwaters of the Acarai, Jauruçu and Guajará rivers, as well as to streams, such as Una (located in the middle Jauruçu River); or they migrate to the Amazon and Xingu rivers. They return to the open areas of large flooded fields at the 
Hoffmann et al. 2021. Conservation of Amazonian manatee (Sirenia: Trichechidae): the case of Extractive Reserve Verde para Sempre, Brazil

Ethnobio Conserv 10:10

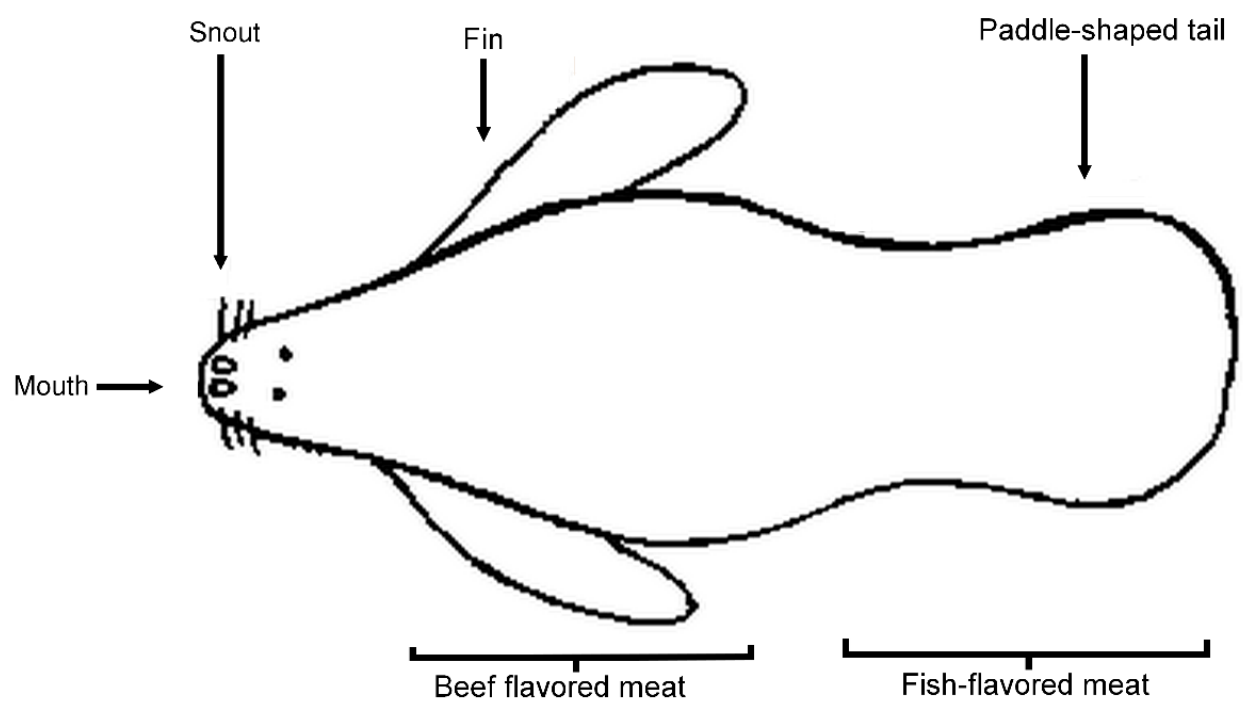

Figure 2. Body topography as identified by the interviewees of RESEX Verde para Sempre (source: adapted from drawing made by an interviewee).

Table 1. Comparative cognition regarding knowledge of ethnoecological aspects of the Amazonian manatee in RESEX Verde para Sempre in the Amazon.

\begin{tabular}{|c|c|}
\hline Remarks from interviewees & Literature \\
\hline $\begin{array}{l}\text { large animal, black, very thick, two shovels and a tail } \\
\text { that looks like a paddle (resident A). }\end{array}$ & $\begin{array}{l}\text { The body is long and cylindrical, has a modified tail } \\
\text { shaped like an oar, rounded, flat and horizontal, long } \\
\text { snout, short thick neck and smooth skin (Best 1984). }\end{array}$ \\
\hline $\begin{array}{l}\text { it is an animal of } 14 \text { to } 18 \text { spans }(1 \text { span }=22 \mathrm{~cm}) \\
\text { (resident B). }\end{array}$ & $\begin{array}{l}\text { At adult age, it reaches approximately } 2.8 \text { to } 3.0 \mathrm{~m} \\
\text { in length (Rosas 1994). }\end{array}$ \\
\hline $\begin{array}{l}\text { is similar to cattle...measures } 8 \text { to } 18 \text { spans (resident } \\
\text { C). }\end{array}$ & $\begin{array}{l}\text { The Amazonian manatee is the largest freshwater } \\
\text { aquatic mammal in South America (Best 1984). }\end{array}$ \\
\hline $\begin{array}{l}\text { the calf suck under the mother's arm, and is born } \\
\text { five spans long (resident D). }\end{array}$ & $\begin{array}{l}\text { The female has one teat under each pectoral flipper } \\
\text { (Best 1982). At birth, it measures } 85 \text { to } 105 \mathrm{~cm} \text { in } \\
\text { length (Rosas 1994). }\end{array}$ \\
\hline $\begin{array}{l}\text { the eyes are small (Gito), like lumps of lead (resident } \\
\text { E). }\end{array}$ & $\begin{array}{l}\text { It has small eyes, which are able to see colors (Griebel } \\
\text { and Schmid1996). }\end{array}$ \\
\hline $\begin{array}{l}\text { it is a very cunning animal, that has time to float, to } \\
\text { take breaths, but if notices any noise, it goes away } \\
\text { (resident F). }\end{array}$ & $\begin{array}{l}\text { Its auditory acuity allows the animal to detect dan- } \\
\text { ger and to escape from it without being seen (Chapla } \\
\text { et al. 2007; Nummela 2009). }\end{array}$ \\
\hline
\end{tabular}

beginning of the rainy season where they reproduce. This period is considered the best to observe manatees and $58 \%(n=18)$ of the interviewees indicated that they spotted females with calves during the rainy season.

Manatees were rarely sighted alone. When two animals were sighted, they were considered either a couple or the mother with a calf. When three individuals were observed, it was the couple with a calf; and when more than five animals were sighted it was because they were breeding.

The interviewees recognized the presence of the
Amazonian manatee by observing their feeding location. They identified 14 types of plants eaten by these animals (Table 2), from which leaves or roots are consumed. The two most cited plants consumed by Amazonian manatee were Eleocharis variegata and Paspalum repens, in $32 \%$ and $22 \%$ of the reports, respectively.

All interviewees were aware that poaching Amazonian manatee is prohibited and stated that it was carried out by the elders of the community or people who had already died. Of these, $48 \%(n=15)$ had learned of the prohibition of poaching before the 
Hoffmann et al. 2021. Conservation of Amazonian manatee (Sirenia: Trichechidae): the case of Extractive Reserve Verde para Sempre, Brazil

Ethnobio Conserv 10:10

Table 2. Example Species of plants consumed by Amazonian manatees according to the 31 interviewees at RESEX Verde para Sempre.

\begin{tabular}{|c|c|c|c|}
\hline $\begin{array}{c}\text { FAMILY } \\
\text { Species } \\
\end{array}$ & Common name1 & Part of plant consumed & $\%$ of citations \\
\hline \multicolumn{4}{|l|}{ Poaceae } \\
\hline Echinochloa polystachya & Canarana & Leaves & $14,00 \%$ \\
\hline Brachiaria purpurascens & Purpuruca & Leaves & $6,00 \%$ \\
\hline Oryza grandiglumis & Arroz & Leaves & $3,00 \%$ \\
\hline Hymenachne amplexicaulis & Rabo de rato & Leaves & $6,00 \%$ \\
\hline Paspalum repens & Peremembeca & Leaves & $8,00 \%$ \\
\hline Leersia hexandra & Pumunga & Leaves & $6,00 \%$ \\
\hline \multicolumn{4}{|l|}{ Cyperaceae } \\
\hline Eleocharis sellowiana & Junquinho & Roots & $3,00 \%$ \\
\hline Eleocharis variegata & Junco & Roots & $14,00 \%$ \\
\hline \multicolumn{4}{|l|}{ Pontederiaceae } \\
\hline Eichhornia crassipes & Mururé barrigudinho & Roots & $15,00 \%$ \\
\hline \multicolumn{4}{|l|}{ Nymphaeacea } \\
\hline Nymphaea sp. & Apé & Roots & $6,00 \%$ \\
\hline \multicolumn{4}{|l|}{ Marantaceae } \\
\hline Ischnosiphon arouma & Arumã & Roots & $3,00 \%$ \\
\hline \multicolumn{4}{|l|}{ Apocynaceae } \\
\hline Rhabdadenia macrostoma & Cipó da beira & Leaves & $3,00 \%$ \\
\hline \multicolumn{4}{|l|}{ Lentibulariaceae } \\
\hline Utricularia foliosa & Samambaia & Leaves and roots & $7,00 \%$ \\
\hline \multicolumn{4}{|l|}{ Convolvulaceae } \\
\hline Ipomoea aquatica & Batatarana & Roots & $6,00 \%$ \\
\hline
\end{tabular}

implementation of RESEX; $32 \%(n=10)$ during the process of implementation of RESEX; $16 \%(n=5)$ through radio and/or television programs; and, $3 \%$ $(n=1)$ by other means.

It should be emphasized that indications of manatee poaching during the period of this study were obtained. Hunting events were both intentional, to meet the need for protein during food shortages, and accidental, by mistake in attempts to spear pirarucu fish (A. gigas) or by entanglement in fishing nets. Most of the interviewees $(61 \%, n=19)$ admitted that they had hunted the Amazonian manatee in the past, and others reported that they participated indirectly in this practice, helping their father or close relatives. Of the 19 interviewees who had already killed manatees, $73.7 \%(n=14)$ were former hunters. Among those, $15.7 \%(n=3)$ reported accidental entanglement in fishing nets, and $10.5 \%(n=2)$ speared the animals by mistake in attempt to catch pirarucu (A. gigas). Some respondents were not hunters $(39 \% ; n=12)$ and reported that they had participated in poaching when they were young or had heard stories of capture events of the Amazonian manatee from their parents and grandparents. Thirteen percent $(n=4)$ of the interviewees reported the commercialization of its meat and $87 \%(n=27)$ its consumption for subsistence. However, according to the interviewees, the commer- cialization and subsistence consumption of manatee meat has not been practiced for at least five years in the RESEX.

Many interviewees $(n=27)$ recalled that the events surrounding the practices of hunting Amazonian manatee were related to celebrations held by parents, grandparents and friends, strengthening social bonds in the community. The taste for manatee meat was highlighted in most reports. The sheets of skin and fat are used for the production of crackling, and oil is used for frying and preserving stewed meat. The oil can also be used as a medicine to relieve muscle pain, swelling, hernia and erysipelas. The skin serves as a plaster for muscle damage. The viscera are used with meat and fat to produce sausage. The tail and fins are cooked in Tucupi, a by-product of cassava. After the slaughter, some meat is roasted and consumed. The rest of the meat can be preserved salted or cooked. However, its consumption is not indicated for people with chronic diseases.

Three techniques were reported to capture the Amazonian manatee: 1) harpoon and stumps in the nose; 2) Pari; 3) Boiadores and Barrancos. The first technique used a metal hook, a rope, stumps and floats (Figure 3), which formed the harpoon. The harpoon consisted of a sturdy, straight wooden rod, with the weight necessary to be thrown at a certain 


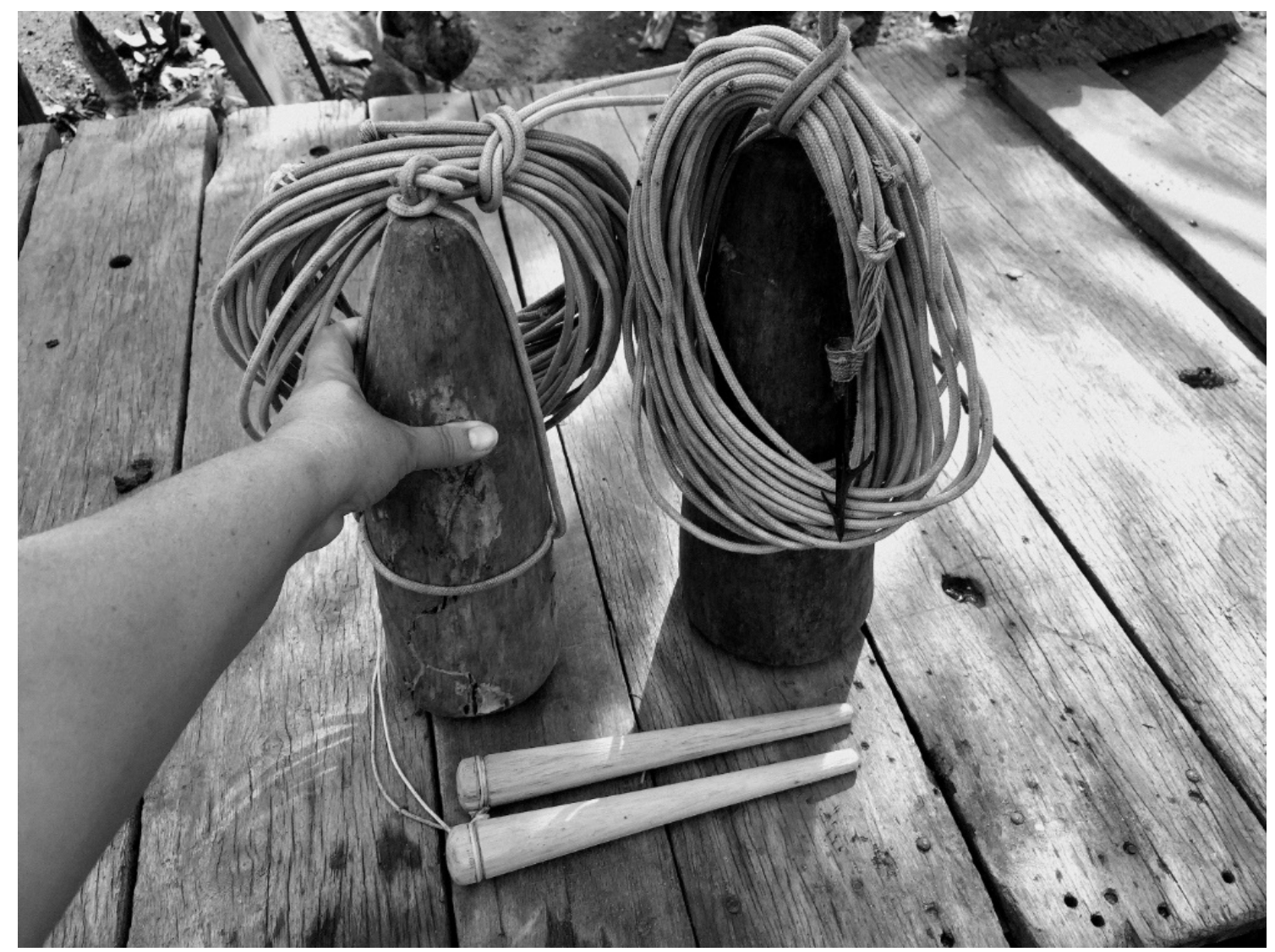

Figure 3. Floats, cord and stumps used to capture an Amazonian manatee, made just for visual demonstration.

distance. A metal hook with sharp tips was set at the end of this rod.

The hook was attached to a rope of 18 to $20 \mathrm{~m}$, which was tied at the other extremity to a buoy, made with wood. The stumps (called Tornos) were made from any type of wood (Figure 3). This technique made it possible to harpoon and suffocate the animal, with the introduction of the stumps in the nostrils. The hunter observed the feeding site for about a week, recording the activity of the manatees and noting breathing intervals. This monitoring is easier in the breeding season or during migration periods because larger groups of more manatees are present. When he found the manatee, the hunter would harpoon and release the rope, which was attached to a light wood floating on the surface of the water. When tired, the animal usually wrapped around the rope, and, at that moment, the stumps were inserted in its nostrils.

The Pari technique consists of a physical barrier built with wooden sticks, placed in a stream to hide the hunter and prevent the animal from moving. Pari is the name of the waiting place used to keep the manatees in low waters.

The Boiadores and Barrancos techniques are characterized by open areas in the middle of aquatic vege- tation, where manatees breathe. Animals usually use these areas for food and shelter. When food supply is scarce, hunters pull out part of the aquatic vegetation, drag it into the middle of the river, and wait in a rowing boat for the manatee to get close enough to catch it with a harpoon.

Illegal fishing was reported by $52 \%(n=16)$ of the interviewees and is carried out with $70 \mathrm{~mm}$ and $80 \mathrm{~mm}$ mesh nets by RESEX residents and people outside this Federal Conservation unit, in the manatees' refuge places (lakes and streams). This activity contributes to the accidental bycatch of young Amazonian manatees. During the survey period, five cases of bycatch occurring over the last five years were reported. The rescue of a calf occurred in the community of Bacabal (middle Guajará River, Aruru River) in November 2016. Local residents frequently see manatees migrating in groups, as well as females with calves throughout the year in this area.

\section{DISCUSSION}

The present study suggests lines of research on the biology and ecology of the Amazonian manatee in the Xingu river region, based on local ecological 
knowledge, as observed in the literature for others species (Silvano and Valbo-Jørgensen 2008; Silvano and Begossi 2010; Ruddle and Davis 2011).

Based on local ecological knowledge, three ethnic species of Amazonian manatees have been identified in the region. This corroborates previous statements of Calvimontes (2009) and Franzini et al. (2013) in other regions of the Amazon. According to Cantanhede et al. (2005), such characteristics are only expressions of the phenotypic variability of skin color, among individuals of a population. We suggest carrying out studies on the genotypic variability of this population to investigate the possible genetic origin of the phenotypic patterns reported by the interviewees.

Our findings showed the migration of the Amazonian manatee to the headwaters of the Acarai, Jauruçu and Guajará rivers during summer. These areas are distant from the community dwellings, thereby less subject to human influence. The migration of the manatees to these areas may be related to the search for food resources (Kendall et al. 2014; Castelblanco-Martinez et al. 2016), but also to avoid predation and poaching (Arraut et al. 2010). We propose that these areas serve as a wildlife refuge to remain as unimpacted as possible by human activities. It could be considered that is necessary to adopt specific measures in the RESEX Verde para Sempre, such as the implantation of a preservation zone, whose general objective is the maintenance of one or more ecosystems, of maximum degree of preservation, serving as restocking source (D'Amico et al. 2018).

As observed in the literature, the installation of hydroelectric power plants in the Amazon region can make the migration difficult and increase the mortality of the Amazonian manatee (Arraut and Marmontel 2016; Arraut et al. 2017). The Belo Monte hydroelectric plant on the Xingu river, the largest in operation in the Amazon region, may have secondary effects, facilitating the mining of bauxite, nickel, copper and gold (Lees et al. 2016). The hydroelectric power station, whose last turbine was activated at the end of 2019, is likely to affect the migration of many aquatic species and eventually have other indirect ecological impacts, such as the availability of food for wildlife.

Concerning to local ecological knowledge, the breeding season and the sighting of females with calf take place during the rainy season. Seasonal breeding may be related to the hydrological cycle and the increase in food supply during the rainy season, as the energy demand for reproduction and to raise calves is high. Best (1982) reported reproductive seasonality in Amazonian manatee and observed a higher frequency of mating and calving in the rainy season, when rivers are flooding, and the abundance of food favors the survival of the calf. Captive females also exhibit re- productive behavior during the rainy season (Amaral et al. 2015). According to Amaral et al. (2015), the reproductive cycle could be primarily triggered by photoperiod or daytime light intensity, while food availability would act as a temporal fine-tuner of reproduction. However, the relation between photoperiod and the reproductive seasonality of wild manatee has yet to be confirmed. These animals appear to present polygamous reproduction, since groups were sighted during the reproductive period (Calvimontes 2009; Carvalho et al. 2017). This sexual behavior would be a strategy to increase the genetic variability of the population. In addition, since female manatees do not cycle continuously, they would be less selective toward males.

The results obtained showed that the Amazonian manatee of this area preferentially eat roots and leaves of 14 species of grasses and water lilies, which would constitute the bulk of their diet. In other regions of the Brazilian Amazon, 31 (Anavilhanas National Park) to 37 (Tapajós - Arapiuns Extractive Reserve and Tapajós National Forest) plant species have been identified as the main component of the manatee diet (Crema et al. 2019). Four plants observed in the present work (Brachiaria purpurascens, Ischnosiphon arouma, Rhabdadenia macrostoma, Ipomoea aquatica) were not cited in the lists of the species consumed by Amazonian manatees in other protected areas. It should be mentioned that $B$. purpurascens and I. aquatica are not native Amazonian species. Possibly, the nutritional value of upland and floodplain plants may be one of the aspects that influence the migratory habit of this species. Roots provide the nutrients for survival in the dry season, while leaves are abundant during the flood season, when the water invades the floodplain areas, forming large fields of forage plants. Bromatological analysis of these foods is necessary to understand the metabolism and energy requirements of the Amazonian manatee.

It could be inferred that there is little evidence of Amazonian manatee hunting in the Xingu region, but that there is an intense human activity in the region, which may impact the production of the local ecosystem. It was shown in the present work that the majority of the participants in this study were adult men, with a low level of education, and the main occupations were farming and herding, fishing and plant extraction. These are the main traditional subsistence activities of the populations living in protected areas in the Amazon (Medina and Barbosa 2016). Quinzeiro Neto et al. (2014) estimated that there are 17 to 18 thousand B. bubalis in RESEX Verde para Sempre, but it should be mentioned that it is an illegal activity in Conservation Units (Brasil 2000). Water buffalo are bred in the RESEX Verde para Sempre, which can be a problem 
for the conservation of the Amazonian manatee, as these animals depend on the floodplain fields for food. It has been observed in other areas of the Brazilian Amazon that extensive water buffalo farming leads to soil compaction, erosion, and the emergence of artificial channels, which accelerate the drainage process of these areas (Meirelles and Mochiutti 2000; Monteiro 2009). In this sense, the progressive replacement of native vegetation by invasive species and the deterioration of water quality have a negative impact on the ecosystem (Meirelles and Mochiutti 2000; Monteiro 2009).

The results of this work reinforce that conservation measures should be rapidly implemented in the region to guarantee that human activities strongly impacting the environment do not affect the migration and survival of the Amazon manatee. These measures include the establishment and protection of refuge areas, as mentioned earlier, and the expansion of the limits of protected areas already existing on the Xingu River region.

In another aspect related to this issue, poaching of Amazonian manatee is mainly for consumption and marketing by some traditional Amazonian communities (Franzini 2008; Calvimontes 2009). Another use involves traditional therapy, using fat for inflammatory problems, which is common throughout Latin America (Alves and Alves 2011). In this regard, the results obtained showed that poaching events seemed infrequent in the RESEX Verde para Sempre, when this study was carried out. As observed in the present study, poaching is an ancient practice currently linked only to the elderly, but this activity may not have been passed on to the younger generation. In addition, only one calf was rescued during the study period, which may indicate that anthropic impacts are not yet intense in this region. In contrast, a higher incidence of rescues is observed in other regions of the Amazon and would be associated with the poaching of mothers (Franzini 2008; Marmontel et al. 2012; Souza 2015).

\section{CONCLUSION}

The results of the study suggest three hypotheses on the biology and ecology of the Amazonian manatee that can be further investigated. The first is the existence of three patterns of phenotypic variability of the Amazonian manatee. The second is that changes in land use by agriculture, livestock and the installation of the hydroelectric plant affect the spatial distribution and seasonal migration of the Amazonian manatees. The third is that the Amazonian manatees show reproductive behavior during the rainy season, in a polygamous way as a strategy of maintenance and genetic variability of the species.
The creation of the RESEX Verde para Sempre has helped to raise awareness in the community that Amazonian manatee poaching is a prohibited activity, but its capture still occurs accidentally. In contrast, the existence of the reserve has not diminished other impacting human activities, such as the breeding of $B$. bubalis. The implementation of this protected area and the ban on poaching are positive strategies for conservation of Amazonian manatee. Likewise, it is necessary to implement sustainable activities for the maintenance of natural resources and guarantee the economic subsistence of the communities that live from agriculture and livestock. We suggest implementing the application of animal husbandry technologies that can be practiced in a more sustainable way. Our results point out the need of identification, delimitation and protection of important areas for Amazonian manatee. The local ecological knowledge acquired during this research may be useful for the development of effective management and conservation strategies for the Amazonian manatee, such as the integral protection of migration areas.

\section{ACKNOWLEDGEMENT}

We thank all the community members of RESEX Verde para Sempre, whose participation and hospitality made this work possible. Instituto Chico Mendes de Conservação da Biodiversidade and Governing Board of RESEX Verde para Sempre for permission to conduct this research. Dr. A. Leyva provided English translation and editing of the manuscript. The authors thank Dr. Michele Singh, from the Caribbean Agricultural Research and Development Institute, for assistance with the helpful comments.

\section{DATA AVAILABILITY}

The data used to support the findings of this study are available from the corresponding author upon reasonable request.

\section{CONFLICT OF INTEREST}

The author(s) declare(s) that they have no conflict of interest related to the publication of this manuscript.

\section{CONTRIBUTION STATEMENT}

Designed the original idea: CMMH; ALFR; DAAG

Carried out the experiment: $\mathrm{CMMH}$

Carried out the data analysis: CMMH; YLP; DAAG

Wrote the first draft of the manuscript: CMMH; YLP; DAAG 
Hoffmann et al. 2021. Conservation of Amazonian manatee (Sirenia: Trichechidae): the case of Extractive Reserve Verde para Sempre, Brazil

Ethnobio Conserv 10:10

Revised and edited the final version of the manuscript: SRS; YLP; PCBJ; DAAG

Supervised the study: DAAG; ALFR

\section{REFERENCES}

Albuquerque UP, Lucena RFP, Alves RRN (2014) Methods and techniques in ethnobiology and ethnoecology. New York: Springer.

Alencar A, Nepstad D; Mcgrath D, Moutinho P, Pacheco P, Del Carman M, Diaz V, Soares Filho BS (2004) Desmatamento na Amazônia: indo além da "emergência crônica". Belém-PA, IPAM.

Alves RR, Alves HN (2011) The faunal drugstore: Animal-based remedies used in traditional medicines in Latin America. Journal of Ethnobiology and Ethnomedicine 7(9): 1-43.

Alves RRN, Rocha LA (2018) Fauna at home: Animals as pets. In: Alves RRN, Albuquerque UP (eds) Ethnozoology: Animals in Our Lives. Academic Press, London, pp. 303-321.

Amaral RS, Rosas FC, da Silva VM, Graham LH, Viau P, Nichi M, Oliveira CA (2015) Seasonal variation in urinary and salivary reproductive hormone levels in Amazonian manatees (Trichechus inunguis). Reproduction Fertility and Development 27(7): 1065-71.

Antunes AP, Fewster RM, Venticinque EM, Peres CA, Levi T, Rohe F, Shepard GH (2016) Empty forest or empty rivers? A century of commercial hunting in Amazonia. Science Advances 2: 1600936.

Arraut EM, Arraut JL, Marmontel M, Mantovani JE, Novo EMLM (2017) Bottlenecks in the migration routes of Amazonian manatees and the threat of hydroelectric dams. Acta Amazonica 47(1): 718.

Arraut EM, Marmontel M (2016) Amazonian manatee threatened with extinction by massive dam-building plan in the Amazon: response to Winemiller et al. 2016. Science 351: 128-129.

Arraut EM, Marmontel M, Mantovani JE, Novo EMLM, Mac Donald DW, Kenward RE (2010) The lesser of two evils: seasonal migrations of Amazonian manatees in the western Amazon. Journal of Zoology 280(3): 247-256.

Aswani S, Hamilton R (2004) Integrating indigenous ecological knowledge and customary sea tenure with marine and social science for conservation of bumphead parrotfish
(Bolpometodon muricatum) in the Roviana lagoon, Solomon Islands. Environmental conservation 31: 1-15.

Bailey K (1994) Methods of social research. 4 ed. The Free Press, New York

Best RC (1981) Foods and feed in habits of wild and captive Sirenia. Mammal Review 11(1): 3-29.

Best RC (1982) Seasonal breeding in the Amazonian manatee, Trichechus inunguis (Mammalia: Sirenia). Biotropica 14(1): 76-78.

Best RC (1984) Trichechus inunguis: vulgo peixe-boi. Ciência Hoje 10(2): 66-72.

Bezerra DMM, De Araujo HFP, Alves AGC, Alves RRN (2013) Birds and people in semiarid northeastern Brazil: symbolic and medicinal relationships. Journal of Ethnobiology and Ethnomedicine 9(1): 3 .

BRASIL (1967) Lei № 5.197, de 3 de janeiro de 1967. Dispõe sobre a proteção à fauna e dá outras providências. Diário Oficial da União Brasilia; 5 Jan 1967. Accessed 31 March 2020.

BRASIL (2000) Lei no $\mathbf{9 . 9 8 5}$, de 18 de julho de 2000. Regulamenta o art. $225, \S 1$ o, incisos I, II, III e VII da Constituição Federal, institui o Sistema Nacional de Unidades de Conservação da Natureza e dá outras providências. Diário Oficial da União Brasilia 1967. Accessed 31 March 2020.

BRASIL (2013) Resolução no 466, de 12 de dezembro de 2012. Dispõe sobre diretrizes e normas regulamentadoras de pesquisas envolvendo seres humanos. Diário Oficial da República Federativa do Brasil, Brasília, DF, 13 jun. 2013. Accessed 14 April 2020.

Calvimontes J (2009) Etnoconocimiento, uso y conservación del manatí amazónico Trichechus inunguis en la Reserva de Desarollo Sostenible Amanã, Brasil. Ms thesis, Universidad Nacional Agraria La Molina, Lima-Peru.

Cantanhede AM, Da Silva VMF, Farias IP, Hrbek T, Lazzarini SM, Alves-Gomes, J (2005) Phylogeography and population genetics of the endangered Amazonian manatee, Trichechus inunguis Natterer, 1883 (Mammalia, Sirenia). Molecular Ecology 14(2): 401-413.

Carvalho CC de, Gräbin DM, Marmontel M (2017) Observation of a potential mating herd in Amazonian manatee. Latin American Journal of Aquatic Mammals 12: 40-44.

Castelblanco-Martínez DN, Kendall S, Orozco DL., 
Hoffmann et al. 2021. Conservation of Amazonian manatee (Sirenia: Trichechidae): the case of Extractive Reserve Verde para Sempre, Brazil

Ethnobio Conserv 10:10

Arévalo-González K (2016) La conservación de los manatíes Trichechus inunguis y Trichechus manatus en áreas no protegidas de Colombia. In: Payán E, Lasso CA, Castaño-Uribe C (eds) Conservación de grandes vertebrados en áreas no protegidas de Colombia, Brasil y Venezuela. (Instituto de Investigación de Recursos Biológicos Alexander von Humboldt, Bogotá, pp. 81-98.

Chapla ME, Nowacek, DP, Rommel SA, Sadler VM (2007) CT scans and 3D reconstructions of Florida manatee (Trichechus manatus latirostris) heads and ear bones. Hearing Research 228: 123-135.

Colares IG (1991) Hábitos alimentares do peixeboi da Amazônia (Trichechus inunguis, Mammalia: Sirenia). Dissertação de mestrado, INPAFUA, Manaus.

Colares IG, Colares EP (2002) Food plants eaten by Amazonian manatees (Trichechus inunguis, Mammalia: Sirenia). Brazilian Archives of Biology and Technology 45(1): 67-72.

Crema LC, da Silva VMF, Piedade MTF (2019) Riverine people's knowledge of the vulnerable Amazonian manatee Trichechus inunguis in contrasting protected areas. Oryx 54(4): 1-10.

D'Amico AR, Coutinho EO; Moraes LFP (2018) Roteiro metodológico para elaboração e revisão de planos de manejo das Unidades de Conservação Federais. Brasília: Instituto Chico Mendes de Conservação da Biodiversidade: ICMBio, 208 p.

Da Silva JMC, Rylands AB, Da Fonseca GAB (2005) The fate of the Amazonian areas of endemism. Conservation Biology 19: 689-694.

De Paula EMS, Da Silva EV (2019) Estrutura e fragmentação geoecológica de paisagem fluvial no baixo rio Xingu - Amazônia centro-oriental. Revista GeoNordeste 2: 95-116.

Ramirez-Gomez SOI, Torres-Vitolas CA, Schreckenberg K, Honzák M, Cruz-Garcia GS, Willcock S, Palacios E, Pérez-Miñana E, Verweij PA, Poppy GM (2015) Analysis of ecosystem services provision in the Colombian Amazon using participatory research and mapping techniques. Ecosystem Services 13: 93-107.

Fearnside PM (2003) A floresta amazônica nas mudanças globais. Manaus: INPA, 134 p.

Franzini AM (2008) Etnoecologia do peixe-boi da Amazônia (Trichechus inunguis) na província petrolífera de Urucu, Amazonas, Brasil. Dis- sertação de mestrado, Universidade Federal do Amazonas, Manaus.

Franzini AM, Castelblanco-Martínez DN, Rosas FCW, da Silva VMF (2013) What do local people know about Amazonian manatees? Traditional ecological knowledge of Trichechus inunguis in the oil province of Urucu. Natura \& Conservação 11(1): 75-80.

Griebel U, Schmid A (1996) Color vision in the manatee (Trichechus manatus). Vision Research 36(17): 2747-2757.

Guterres-Pazin M (2010) Ecologia alimentar do peixe-boi da Amazônia (Trichechus inunguis) (Sirenia, Trichechidade) nas Reservas de Desenvolvimento Sustentável Mamirauáe Amanã. Dissertação de mestrado, INPA, Manaus.

ICMBio (2013) Reserva Extrativista Verde para Sempre. Accessed 18 august 2015.

Isaac VJ, Almeida MC, Cruz REA, Nunes LG (2015) Artisanal fisheries of the Xingu river basin in Brazilian Amazon. Brazilian Journal of Biology 75(3): S125-S137.

Jenkins RKB, Keane A, Rakotoarivelo AR, Rakotomboavonjy V, Randrianandrianina FH, Razafimanahaka HJ, Ralaiarimalala SR, Jones PG (2011) Analysis of patterns of bushmeat consumption reveals extensive exploitation of protected species in eastern Madagascar. Plos One 6: 12.

Jepson P, Ladle RJ (2009) Governing birdkeeping in Java and Bali: evidence from a household survey. Oryx 43: 364-374.

Kendall S., Ahue C, Orozco, DL. Peña LH (2014) Conservación y monitoreo de los manatíes en los humedales de Tarapoto. In: Trujillo F, Duque S (eds) Los Humedales de Tarapoto: aportes al conocimiento sobre su biodiversidad y uso Fundación Omacha, Bogotá, pp. 374-397.

Kress WJ, Heyer WR, Acevedo P, Coddington J, Cole D, Erwin TL, Meggers BJ, Pogue M, Thorington RW, Vari RP, Weitzman MJ, Weitzman SH (1998) Amazonian biodiversity: Assessing conservation priorities with taxonomic data. Biodiversity and Conservation 7: 1577-1587.

Lees AC, Peres CA, Fearnside PM, Schneider M, Zuanon JAS (2016) Hydropower and the future of Amazonian biodiversity. Biodiversity and Conservation 25: 451-466.

Marmontel M, de Souza D, Kendall S (2016) Trichechus inunguis. The IUCN Red List of Threatened Species 2016: 
Hoffmann et al. 2021. Conservation of Amazonian manatee (Sirenia: Trichechidae): the case of Extractive Reserve Verde para Sempre, Brazil

Ethnobio Conserv 10:10

e.T22102A43793736. doi: 10.2305/IUCN.UK.20162.RLTS.T22102A43793736.en. Accessed 24 march 2018.

Marmontel M, Rosas FC, Kendall WS (2012) The Amazonian manatee. In: Sirenian conservation: issues and strategies in developing countries. University Press of Florida, Gainesville, pp.47-53.

Medina G. Barbosa C (2016) A questão produtiva nas reservas extrativistas. Novos Cadernos NAEA 19 (2): 69-88.

Meirelles PRL, Mochiutti S (2000) Impactos Ambientais da bubalinocultura nos campos inundáveis do Amapá. In Workshop ECOLAB V, Ecossistemas Costeiros Amazônicos: boletim de resumos. IEOPA, Macapá, p. 57-61.

Monteiro FJC (2009) Impactos ambientais causados pelos búfalos asselvajados nos campos inundáveis da Estação Ecológica de MaracáJipioca (Costa Atlântica do Amapá), 2009. 50 f. Dissertação de mestrado, Universidade Federal do Amapá, Macapá.

Morsello C, Yagüe B, Beltreschi L, Van Vliet N, Adams C, Schor T, Quiceno-Mesa MP, Cruz D (2015) Cultural attitudes are stronger predictors of bushmeat consumption and preference than economic factors among urban amazonians from brazil and Colombia. Ecology and Society 20(4): 21

Nummela, S (2009) Hearing. In: Perrin, WF, Würsig, B, Thewissen, JGM (eds.) Encyclopedia of Marine Mammals. Elsevier Academic Press, London, pp. 553-562.

Quinzeiro Neto T, Lourenço Junior JB, Garcia AR, Santos JC, Santos MAS, Neres LS (2014) A bubalinocultura em areas de reserva extrativista na amazonia: o caso da resex verde para sempre, Porto de Moz, Estado do Para. Amazônia: Ciência e Desenvolvimento 9: 115-136.

Ripple WJ, Abernethy K, Betts MG, Chapron G, Dirzo R, Galetti M, Levi T, Lindsey PA, Macdonald DW, Machovina B, Newsome TM, Peres CA, Wallach AD, Wolf C (2016) Bushmeat hunting and extinction risk to the world's mammals. Royal Society Open Science 3: 160498.

Rosas FCW (1994) Biology, conservation and status of the amazonian manatee Trichechus inunguis. Mammal Review 24(2): 49-59.

Rosas FCW, Pimentel TL (2001) Order Sirenia (Manatees, dugongs, sea cows). In: Fowler ME, Cubas ZS (eds) Biology, medicine and surgery of South American wild animals. Iowa
State University Press, Iowa. pp. 352-362.

Ruddle K, Davis A (2011) What is "ecological" in local ecological knowledge? Lessons from Canada and Vietnam. Society $\&$ Natural Resources 24(9): 887-901.

Silva JD, Montes D, Elías R (2014) Conocimientos, conservación y avistamiento del manatí amazónico (Trichechus inunguis), según los pobladores de la cuenca del rio Ucayali (Loreto, Perú). Salud y Tecnología Veterinaria 2: 32-38.

Silvano RAM, Begossi A (2010) What can be learned from fishers? An integrated survey of fishers' local ecological knowledge and bluefish (Pomatomus saltatrix) biology on the Brazilian coast. Hydrobiologia 637: 3-18.

Silvano RAM, Valbo-Jørgensen J (2008) Beyond fishermen's tales: contributions of fishers' local ecological knowledge to fish ecology and fisheries management. Environment, Development and Sustainability 10, 657.

Souza DAD (2015) Peixe-boi da amazônia (Trichechus inunguis, Natterer 1883): Mortalidade e uso do habitat na Reserva de Desenvolvimento Sustentável Piagaçu-Purus, Amazonas, Brasil. Dissertação de mestrado, INPA, Manaus.

Tófoli RM, Dias RM, Zaia Alves GH, Hoeinghaus DJ, Gomes LC, Baumgartner MT, Agostinho AA (2017) Gold at what cost? Another mega project threatens biodiversity in the Amazon. Perspectives in Ecology and Conservation 15(2): 129-131.

Venter O, Sanderson EW, Magrach A, Allan JR, Beher J, Jones KR, Possingham HP, Laurance WF, Wood P, Fekete BM, Levy MA, Watson JEM (2016) Sixteen years of change in the global terrestrial human footprint and implications for biodiversity conservation. Nature Communications 7 : 12558 .

Vergara S (2012) Métodos de coleta de dados no campo, 2 eds. Atlas

Zaniolo GR (2006) Etnoconhecimento do peixeboi amazônico Trichechus inunguis (Natterer, 1883) pelos pescadores de Novo Airão, Amazonas, Brasil. Dissertação de mestrado, Universidade Federal do Amazonas, Manaus.

Zappes CA, Gatts CEN, Lodi LF, Simões-Lopes PC, Laporta P, Andriolo A, Di Beneditto APM (2014) Comparison of local knowledge about the bottlenose dolphin (Tursiops truncatus Montagu, 1821) in the Southwest Atlantic Ocean: New 
research needed to develop conservation management strategies. Ocean and Coastal Management 98: 120-129.

Received: 17 April 2020

Accepted: 17 November 2020

Available: 22 November 2020 